Tropical Journal of Pharmaceutical Research October 2017; 16 (10): 2411-2416

ISSN: $1596-5996$ (print); 1596-9827 (electronic)

(C) Pharmacotherapy Group, Faculty of Pharmacy, University of Benin, Benin City, 300001 Nigeria.

All rights reserved.

Available online at http://www.tjpr.org

Original Research Article

http://dx.doi.org/10.4314/tjpr.v16i10.14

\title{
Effect of rosella (Hibiscus sabdariffa L) extract on glutathione-S-transferase activity in rats
}

\author{
Nurkhasanah ${ }^{1}$, Laela Hayu Nurani ${ }^{1}$ and Zainur Rahman Hakim ${ }^{1,2}$ \\ ${ }^{1}$ Faculty of Pharmacy, University of Ahmad Dahlan, Jl. Prof. Soepomo, Janturan, Yogyakarta, ${ }^{2}$ Faculty of Pharmacy, \\ Universitas Muhammadiyah Purwokerto, JI Letjen Soepardjo Roestam, Purwokerto, Indonesia \\ *For correspondence: Email: nurkhas@gmail.com; Tel: +6285878322867
}

Sent for review: 21 December 2016

Revised accepted: 10 September 2017

\begin{abstract}
Purpose: To determine the effect of rosella (Hibiscus sabdariffa $L$ ) extract on glutathione-S-trasferase (GST) activity and its hepatoprotective effect.

Methods: A total of 25 rats were divided randomly into 5 groups (5 rats per group). Group I served as the baseline, group II was the negative control group, while groups III, IV and V were treated with rosella extract at doses of 10,50 and $100 \mathrm{mg} / \mathrm{kg} /$ day, respectively for 35 days. On day 36, the animals were given a single dose of dimethyl benz(a)anthracene (DMBA) orally. After one week, blood was taken from the sinus orbitalis for measurement of serum glutamate pyruvate transaminase (SGPT) and serum glutamate oxaloacetate transaminase (SGOT) activities by a kinetic method with Dlasys $\circledast$ kit. The activity of GST was measured in liver homogenate using 1-choloro-2,4-dinitrobenzene (CDNB) method, while the expression of GST gene was determined by reverse transcriptase polymerase chain reaction (RT-PCR)

Results: Treatment with rosella extract at 10,50 and $100 \mathrm{mg} / \mathrm{kg}$ for 35 days led to significant increases in GST activity relative to the control group. In addition, serum SGPT and SGOT activities were significantly decreased. There were significant increases in the expression of GST gene as evidenced by increased GST band intensity.

Conclusion: These results indicate that rosella possesses significant hepatoprotective effect against hepatic injury caused by DMBA treatment. Thus, rosella may be useful for the prevention of oxidative stress caused by free radicals produced from pollutants and foods.
\end{abstract}

Keywords: Hibiscus sabdariffa, Rosella, Glutamate pyruvate transaminase (SGPT), Glutamate oxaloacetate transaminase (SGOT), glutathion-S-transferase (GST)

Tropical Journal of Pharmaceutical Research is indexed by Science Citation Index (SciSearch), Scopus, International Pharmaceutical Abstract, Chemical Abstracts, Embase, Index Copernicus, EBSCO, African Index Medicus, JournalSeek, Journal Citation Reports/Science Edition, Directory of Open Access Journals (DOAJ), African Journal Online, Bioline International, Open-J-Gate and Pharmacy Abstracts

\section{INTRODUCTION}

Free radicals are highly reactive molecules since they have one or more unpaired electrons. Their reactivities are reduced by electron donation from other molecules. Oxidative stress plays a major role in the development of chronic and degenerative diseases such as cancer, arthritis, aging, autoimmune disorders, cardiovascular disease and neurodegenerative disease [1]. The human body produces endogenous antioxidants to fight oxidative stress. However, in the presence of excess levels of pro-oxidants, exogenous antioxidants from food and supplements are needed. Endogenous and exogenous antioxidants act to prevent and repair damage caused by reactive oxygen and nitrogen species; they boost the immune system and reduce the risk of cancer and degenerative diseases $[1,2]$. 
Polycyclic aromatic hydrocarbons (PAHs) are environmental pollutants generated by the combustion of fuel, wood and other organic materials. They are also found in cigarette smoke, grilled food and motor vehicle exhaust fumes [3,4]. Dimethyl benz (a) anthracene (DMBA), a prototype of $\mathrm{PAH}$, is a carcinogenic and immunosuppressive agent [5, 6,]. It is also a hepatotoxic agent [7,8]. Damaged liver cells release various enzymes into the blood. These enzymes such as SGPT and SGOT are important indicators of liver damage [9].

Rosella ( $H$. sabdariffa) possesses antioxidant properties [10]. Previous studies reported that rosella exerted hepatoprotective effect against toxicity from paracetamol [11], carbon tetrachloride [12] and streptozotocin [13]. It has also been reported that rosella extract treatment reduced SGPT, SGOT and ALP activities after DMBA exposure [14]. The objective of this research was to investigate the protective effect of rosella against DMBA-induced hepatotoxicity with regards to its effect on GST activity and GST gene expression.

\section{EXPERIMENTAL}

\section{Plant material}

Rosella calyx was obtained from East Java. The specimen was identified at the Laboratory of Biology, Ahmad Dahlan University by Assoc Prof. Hadi Sasongko on May 2014 (identification no. B/B.12/1030/VII/2014). The calices were dried and ground into powder. Extraction was carried out with $70 \%$ ethanol, followed by evaporation in a rotary evaporator at $50{ }^{\circ} \mathrm{C}$ to get the concentrated extract.

\section{Determination of total flavonoids}

The total flavonoid content of the extract was determined using quercetin as standard [15]. The extract (1gram) was dissolved in $100 \mathrm{~mL}$ of $70 \%$ ethanol. Then $3 \mathrm{~mL}$ of the solution was made up to $10 \mathrm{~mL}$ with $70 \%$ ethanol. To $0.5 \mathrm{~mL}$ of this extract solution was sequentially added $1.5 \mathrm{~mL}$ of ethanol, $0.1 \mathrm{~mL} 10 \% \mathrm{AlCl}_{3} ; 0.1 \mathrm{~mL}$ of $1 \mathrm{M} \mathrm{Na}$ acetate; and $2.8 \mathrm{~mL}$ of distilled water. The resultant solution was mixed to homogeneity, and then read at $430 \mathrm{~nm}$ in a UV-VIS spectrophotometer.

\section{Animal treatments}

Animal handling in this research was approved by the Research Ethical Committee of Ahmad Dahlan University (approval ref no. 011505043). The care and use of animals was in line with the
Guide For The Care and Use of Laboratory Animals published by National Research Council of the National Academies [16]. Male Sprague Dawley rats (25) were divided into 5 groups, each group consisting of 5 male rats. The animals were acclimatized for 1 week to the experimental environment. Group I, the normal group, received feed and drinking water ad libitum. Group II was treated with a single oral dose of DMBA at $75 \mathrm{mg} / \mathrm{kg}$. Groups III, IV, V were treated with the extract at doses of 10,50 and $100 \mathrm{mg} / \mathrm{kg}$, respectively daily for 35 days. All treatments were administered orally. After 35 days, rats in the extract groups were treated with a single oral dose of DMBA at $75 \mathrm{mg} / \mathrm{kg}$. Blood samples were collected from orbital sinus after 1 week for SGPT and SGOT analyses. The rats were thereafter sacrificed under $\mathrm{CO}_{2}$ gas anaesthesia, and their liver were excised for GST analysis.

\section{Determination of SGPT and SGOT activities}

The activities of SGPT and SGOT were assayed colorimetrically using Diasys ${ }^{\circledR}$ kits as per manufacturer's instructions.

\section{Determination of GST activity}

The activity of GST was measured in liver homogenates using 1-choloro-2,4-dinitrobenzene (CDNB) method (17). Liver tissue (100 mg) was homogenized with $1 \mathrm{~mL}$ of $0.1 \mathrm{M}$ phosphate buffer, $\mathrm{pH}$ 7.5. The homogenate was centrifuged at $10,000 \mathrm{rpm}$ and $4{ }^{\circ} \mathrm{C}$ for $30 \mathrm{~min}$. The supernatant was then centrifuged further at $15,000 \mathrm{rpm}$ for $30 \mathrm{~min}$. at $4{ }^{\circ} \mathrm{C}$. The supernatant from the second centrifugation was the cytosolic fraction containing GST. It was stored at $-20{ }^{\circ} \mathrm{C}$ and used for GST assay. In the assay, $702.5 \mu \mathrm{L}$ of $0.1 \mathrm{M}$ phosphate buffer $\mathrm{pH} 6.5$ was added to $17.5 \mu \mathrm{L}$ of the liver cytosol fraction, $15 \mu \mathrm{L}, 50$ $\mathrm{mM} \mathrm{GSH}$, and $15 \mu \mathrm{L}$ of $50 \mathrm{mM}$ CDNB (dissolved in ethanol) in a1-mL cuvette. The GS-DNB 194 conjugate product was measured at $340 \mathrm{~nm}$ from 0 to $3 \mathrm{~min}$ in a spectrophotometer. The GST activity was stated as average rate of absorbance per minute.

\section{GST gene expression by RT-PCR}

The expression of GST gene was monitored by RT-PCR. Liver tissue (100 mg) was extracted with $1000 \mu \mathrm{L}$ of Trizolß, re-suspended 20-30 times, and kept at room temperature for $5 \mathrm{~min}$. The mixture was added to $200 \mu \mathrm{L}$ of chloroform, incubated at room temperature for $15 \mathrm{~min}$ and centrifuged at $12,000 \mathrm{rpm}$ for $15 \mathrm{~min}$ at $4{ }^{\circ} \mathrm{C}$. The supernatant $(400 \mu \mathrm{L})$ was taken and mixed with $500 \mu \mathrm{L}$ of isopropanol, shaken for 5 seconds and 
then centrifuged at $12,000 \mathrm{rpm}$ for $5 \mathrm{~min}$ at $4{ }^{\circ} \mathrm{C}$. The supernatant was then discarded and the pellet was washed and shaken gently with $1 \mathrm{~mL}$ of $75 \%$ ethanol. The mixture was vortexed and centrifuged at $9800 \mathrm{rpm}$ for $5 \mathrm{~min}$ at $4{ }^{\circ} \mathrm{C}$. The supernatant was discarded and the pellet was dried at room temperature and re-suspended in RNase-free water followed by incubation at 60 ${ }^{\circ} \mathrm{C}$ for $10 \mathrm{~min}$. It was thereafter stored at $-80{ }^{\circ} \mathrm{C}$ as RNA Stock.

\section{Synthesis of cDNA}

The RNA stock (5 mg) was added to $1.0 \mathrm{~mL}$ of a universal primer (Oligo dT) and made up to a volume of $12 \mu \mathrm{L}$ with RNase-free water (RFW). This was the RNA template. The master mix solution was prepared by mixing $4 \mu \mathrm{L}$ of $5 \mathrm{x}$ reaction buffer, $1 \mu \mathrm{L}$ of ribolock $\mathrm{RNase}$ inhibitor, $2 \mu \mathrm{L}$ of $10 \mathrm{mM}$ dNTP mix, and $1 \mu \mathrm{l}$ RevertAidMMuLV reverse transcriptase. After gentle mixing, it was centrifuged at $3500 \mathrm{rpm}$ for $1 \mathrm{~min}$. Then, each master mix was added to RNA template and mixed gently. Each sample was incubated in a thermal cycler at $42{ }^{\circ} \mathrm{C}$ for $60 \mathrm{~min}$ and terminated at $70{ }^{\circ} \mathrm{C}$ for $5 \mathrm{~min}$.

\section{Polymerase chain reaction (PCR)}

The process of PCR was initiated with the preparation of PCR Master Mix by putting into a 25-mL microtube 0.5 DreamTaq green PCR, 1 $\mu \mathrm{L}$ of $10 \mu \mathrm{M}$ GST forward primer, $10 \mu \mathrm{M}$ of $1 \mu \mathrm{L}$ GST reverse primer, $4 \mu \mathrm{L}$ of cDNA template and $19 \mu \mathrm{L}$ of RFW, followed by gentle vortex-mixing. The mixture was then placed on the PCR thermal cycler machine. Initiation step (initial denaturation) was at a temperature of $95^{\circ} \mathrm{C}$ for 3 min, followed by 35 cycles at $95^{\circ} \mathrm{C}$ for $30 \mathrm{sec}$ (denaturation), $55^{\circ} \mathrm{C}$ for $30 \mathrm{sec}$ (annealing), 72 ${ }^{\circ} \mathrm{C}$ for $1 \mathrm{~min}$ (elongation or automated extension), and at $72{ }^{\circ} \mathrm{C}$ for $10 \mathrm{~min}$ (final extension). The GSTp bp ( $\mathrm{C}$ to $\mathrm{T}$ ) used as primers (IDT, Madison, AL, Singapore) were:

GSTP 1 - 5'-CAT GCC TAT GAT ACT GGG ATA-3';

GSTP 2 - 5'-CTA CTT GTT ACT CCA TTG GGC -3 '.

The PCR results were subjected to agarose gel electrophoresis. Agarose gel was prepared from agarose gel (Invitrogen, New Zealand) $2 \%$ with $1 \mathrm{x}$ TBE (Tris Boric EDTA) buffer and $5 \mu \mathrm{L}$ ethidium bromide. Electrophoresis was carried out at $150 \mathrm{~V}$ for $30 \mathrm{~min}$. The electrophoresis result was captured by photographing the ethidium bromide flourescense in a dark room.

\section{Statistical analysis}

Data were expressed as mean $\pm S D$ of three replications. Quantitative data were compared with control values and analyzed statistically using one-way ANOVA with SPSS software. The significance level was set at $p<0.05$.

\section{RESULTS}

\section{Total flavonoid content}

The total flavonoid content of roselle extract was $0.371 \pm 0,011 \%$. Antocyanin was one of abundant flavonoids in rosella calyx.

\section{Effect of rosella extract on SGPT and SGOT activities}

The rosella extract led to significant decreases in DMBA-induced elevations in the activities SGPT and SGOT (Table 1).

Table 1: Levels of SGPT and SGOT after treatment with rosella extract and DMBA

\begin{tabular}{lll}
\hline Group & SGPT (U/L) & SGOT (U/L) \\
\hline Normal & $22.58 \pm 0.62^{*}$ & $18.69 \pm 0.63^{*}$ \\
Negative control & $26.58 \pm 1.07$ & $21.73 \pm 0.83$ \\
Rosella $(10 \mathrm{mg} / \mathrm{kg})$ & $24.28 \pm 1.05^{\star}$ & $18.69 \pm 0.63^{*}$ \\
Rosella $(50 \mathrm{mg} / \mathrm{kg})$ & $22.46 \pm 0.46^{*}$ & $18.21 \pm 0.62^{*}$ \\
Rosella $(100 \mathrm{mg} / \mathrm{kg})$ & $22.09 \pm 0.27^{*}$ & $18.09 \pm 0.46^{*}$ \\
\hline${ }^{\star}$ Significantly different from negative control group $(p<$ \\
0.05). Data were expressed as mean $\pm S D$ of three \\
replications
\end{tabular}

The results showed that DMBA was hepatotoxic, as indicated by the significant increases in SGPT and SGOT levels after DMBA treatment $[12,17]$. Treatment with rosella extract at 10,50 and 100 $\mathrm{mg} / \mathrm{kg}$ for 35 days decreased the activities of SGPT to normal levels.

\section{Effect of rosella extract on GST activity}

Treatment with DMBA decreased GST activity in the liver. However, these decreases were reversed by the rosella extract, which resulted in increases in the activities of GST (Table 2).

Table 2: Effect of rosella extract on hepatic activity of GST in DMBA-treated rats

\begin{tabular}{ll}
\hline Group & Activity (mU/mg) \\
\hline Normal & $11.233 \pm 7.332$ \\
Negative control & $6.533 \pm 2.838$ \\
Rosella $(10 \mathrm{mg} / \mathrm{kg})$ & $7.333 \pm 1.528$ \\
Rosella $(50 \mathrm{mg} / \mathrm{kg})$ & $6.333 \pm 1.155$ \\
Rosella $(100 \mathrm{mg} / \mathrm{kg})$ & $14.500 \pm 3.536^{\star}$
\end{tabular}

${ }^{*}$ Significantly different from negative control group $(p<$ $0.05)$. Data were expressed as mean $\pm S D$ of three replications 
Treatment with rosella at a dose of $100 \mathrm{mg} / \mathrm{kg}$ significantly increase GST activity, but not at lower doses.

\section{Effect of rosella extract on GST gene expression}

The purity of RNA was determined by the ratio of absorbances at $260 \mathrm{~nm}$ and $280 \mathrm{~nm}\left(\mathrm{~A}_{260 / 280}\right)$ (Table 3 ). The best ratio was 1.8-2.0. The ratio obtained for the isolated RNA was 1.8-3.6, which indicated some DNA impurity, since $A_{260 / 280}>2.0$, but no protein impurity $\left(A_{260 / 280}>1.8\right)$. It was also revealed that there was an increasing level of GST gene expression in the rosella extracttreated groups (Figure 1). Thus, treatment with rosella for 35 days (sub-chronic exposure) influenced the level of GST at the molecular level.

Table 3: $A_{260 / 280}$ ratio of $\mathrm{RNA}$ isolated from rosella extract-treated, DMBA-exposed rats

\begin{tabular}{lc}
\hline Group & $\begin{array}{c}\text { Ratio } \\
\left(\mathbf{A}_{\text {260/280 }}\right)\end{array}$ \\
\hline Normal & 2.136 \\
Negative control & 1.832 \\
Rosella $(10 \mathrm{mg} / \mathrm{kg})$ & 2.839 \\
Rosella $(50 \mathrm{mg} / \mathrm{kg})$ & 3.600 \\
Rosella $(100 \mathrm{mg} / \mathrm{kg})$ & 2.694 \\
\hline
\end{tabular}

Figure 1: GST gene expression from RT-PCR of rosella extract-treated, DMBA-exposed rats. M: marker; (1) normal; (2): negative control, (3) $10 \mathrm{mg} / \mathrm{kg}$, (4) $50 \mathrm{mg} / \mathrm{kg}$, (5) $100 \mathrm{mg} / \mathrm{kg}$, (6) rosella-treated, 100 $\mathrm{mg} / \mathrm{kg}$ control without DMBA induction

\section{DISCUSSION}

Rosella has been reported to have antioxidant effects [10]. Antioxidant property is important for protection of the liver from damage caused by free radicals. Studies have shown that rosella is hepatoprotective against liver damage from exposure to paracetamol, [11]; carbon tetrachloride [12], and streptozotocin [13]. Flavonoids are known to possess antioxidant properties. This antioxidant property is expected to neutralize the damaging effects of free radicals, including DMBA. The hydroxy phenolic groups of flavonoids scavenge free radicals by donating their lone pair of electrons. Enzymatic activation of PAHs leads to the generation of active oxygen species such as peroxides and superoxide anion radicals, which induce oxidative stress in the form of lipid peroxidation. Formation of reactive oxygen species (ROS) in hepatocytes is deleterious to the liver because oxidative stress plays an important role in liver injury [9].

Many of the members of the PAH family are toxic, carcinogenic and immunotoxic [5]. DMBA is metabolized in the liver to a more toxic form which is involved the activation of cytochrome P450 to more reactive intermediates such as epoxides, dihydrodiol and radical cations. Epoxides and dihydrodiols bind covalently to amino groups of purines to form stable and unstable DNA adducts. The cytochrome P450 enzyme CYP1A1 or CYP1B1, and microsomal hydrolase metabolize DMBA to DMBA-3,4-diol1,2-epoxide (DMBA-DE). These enzymes are located in hepatic cells and extra-hepatic tissues such as lung, mammary gland, spleen, kidney, prostate, uterus, and heart [4].

The elimination of DMBA-DE from the body is accelerated in the presence of the antioxidant enzyme glutathione-S-transferase (GST) [6]. PAHs are metabolized by cytochrome P450 monooxygenases (CYPs). Enzymes of the CYP1A sub-family are involved in phase I biotransformation of xenobiotics in many vertebrates. Substrates for CYP1A are of planar conformation, and the expression of CYP1A mRNA is regulated by binding of planar aromatic hydrocarbons to the cytosolic aryl hydrocarbon receptor (AhR). The second step in the metabolism of PAH is catalyzed by phase II biotransformation enzymes, amongst which is GST, which is also regulated by the AhR [18].

The increased activity of GST in the extracttreated group is an indication of the hepatoprotective effect of rosella against DMBA damage, and its ability to reverse the oxidative stress caused by DMBA. In the treated groups, the increase in activity of GST implied enhanced capacity to detoxify DMBA to DMBA-DE. This is supported by the concomitant decreases in levels of SGPT and SGOT. Previous reports showed that dietary quercetin significantly decreased the antioxidant activities of phase II hepatic enzymes [18].

In the present study, results from PCR showed significant decreases in GST expression after 
DMBA treatment, which is an indication that DMBA has adverse effect on GST gene expression. However, treatment with rosella extract reversed this effect. In a previous study, it was shown that oral administration of anthocyanin-rich rosella extract increased the activities of SOD, catalase and GPx. Thus, the results obtained in the study can be attributed to the radical-scavenging effects of the antioxidant principles in the extract.

\section{CONCLUSION}

The findings of this study indicate that rosella extract has hepatoprotective effect against DMBA-induced liver injury as seen from the reversal of decreases in GST gene expression, increases in GST activity and reduction in SGPT and SGOT levels.

\section{DECLARATIONS}

\section{Acknowledgement}

The authors thank Directorate of Higher Education, Ministry of National Education for funding this research through a Postgraduate Research Grant.

\section{Conflict of Interest}

No conflict of interest associated with this work.

\section{Contribution of Authors}

The authors declare that this work was done by the authors named in this article and all liabilities pertaining to claims relating to the content of this article will be borne by them.

\section{Open Access}

This is an Open Access article that uses a funding model which does not charge readers or their institutions for access and distributed under the terms of the Creative Commons Attribution License (http://creativecommons.org/licenses/by/ 4.0) and the Budapest Open Access Initiative (http://www.budapestopenaccessinitiative.org/rea d), which permit unrestricted use, distribution, and reproduction in any medium, provided the original work is properly credited.

\section{REFERENCES}

1. Valko M, Rhodes CJ, Moncol J, Izakovic M, Mazur M. Free radicals, metals and antioxidants in oxidative stress-induced cancer. Chem Biol Interact. 2006; 160: $1-40$.
2. Parthasarathy $S$, Santanam $N$, Ramachandran $S$, Meilhac O. Oxidants and antioxidants in atherogenesis: an appraisal. J Lipid Res. 1999; 40: 2143-2157.

3. Burchiel SW, Hadley WM, Barton SL, Fincher RH, Lauer LD, Dean JH. Persistent suppression of humoral immunity produced by 7,12-dimethylbenz(a)anthracene (DMBA) in B6C3F1 mice: Correlation with changes in spleen cell surface markers detected by flow cytometry. Int J Immunopharmacol. 1988; 10(4): 369-376.

4. Gao J, Lauer FT, Dunaway S, Burchiel SW. Cytochrome P450 $1 B 1$ is required for 7,12-dimethylbenz(a)anthracene $(D M B A)$ induced spleen cell immunotoxicity. Toxicol Sci. 2005; 86(1): 68-74.

5. Gao J, Mitchell LA, Lauer FT, Burchiel SW. p53 and ATM / ATR Regulate 7 , 12-Dimethylbenz [ a ] anthraceneInduced Immunosuppression. Mol Pharmacol. 2008; 73(1): 137-146.

6. Buters J, Quintanilla-martinez L, Schober W, Soballa VJ, Hintermair $J$, Wolff $T$, et al. CYP1B1 determines susceptibility to low doses of 7, 12-dimethylbenz [a] anthracene- induced ovarian cancers in mice: correlation of CYP1B1-mediated DNA adducts with carcinogenicity. 2003; 24(2): 327-334.

7. Singh H, Bedi PS, Singh B. Hepatoprotective Activity of Turmeric and Garlic against 7-12, Dimethylbenzanthracene Induced Liver Damage in Wistar Albino Rats. European J Med Plants. 2011; 1(4): 162-170.

8. El-gerbed MSA. Research Journal of Pharmaceutical, Biological and Chemical. Res J Pharm Biol Chem Sci. 2013; 4(3): 1534-1548.

9. Singh A, Bhat TK, Sharma OP. Clinical Biochemistry of Hepatotoxicity. Clin Toxicol. 2011; S4:001: 1-19.

10. Anokwuru PC, ljeoma E, Ajibaye O, Adesuyi OA. Polyphenolic content and antioxidant activity of hibiscus sabdariffa calyx. Res J Med Plant. 2011; 5(5): 557-566.

11. Sujono TA, Widiatmoko YW. Influence Dried Flower of Hibiscus sabdariffa Linn Infusion on Serum Glutamate Pyruvate Transaminase (SGPT) Level against Paracetamol Induced Liver Injury in Rats. Int Conf Res Appl Tradit Complement Altern Med Heal Care. 2012; 22-23.

12. Adetutu A, Owoade AO. Hepatoprotective and Antioxidant Effect of Hibiscus Polyphenol Rich Extract (HPE) Against Carbon Tetrachloride $\left(\mathrm{CCL}_{4}\right)$ - Induced Damage in Rats. Br J Med Med Res. 2013; 3(4): 15741586.

13. Adeyemi DO, Ukwenya VO, Obuotor EM, Adewole SO. Anti-hepatotoxic activities of Hibiscus sabdariffa $L$. in animal model of streptozotocin diabetes-induced liver damage. BMC Complement Altern Med. 2014; 14(277): 1-11.

14. Nurkhasanah, Rahardhian MRR. Hepatoprotective Effect of Hibiscus Sabdariffa L Extract on 7, 12-dimethylbenz (a) antracene (dmba) Induced Rat. Int J Biol Med Res. 2015; 3(1): 4705-4708.

15. Chang C, Yang M, Wen H, Chern J. Estimation of Total Flavonoid Content in Propolis by Two Complementary

Trop J Pharm Res, October 2017; 16(10): 2415 
Colorimetric Methods. J Food Drug Anal. 2002; 10(3): 178-182.

16. Council NR. Guide for the care and use of laboratory animals. eight edit. Washington DC; 2011.

17. Habig WH, Pabst MJ, Jakoby WB. Glutathione Stransferases: The first enzymatic step in mercapturic acid formation. J Biol Chem. 1974; 249: 7130-7139.

18. Galván N, Page TJ, Czuprynski CJ, Jefcoate CR. Benzo(a)pyrene and 7,12-dimethylbenz(a)anthrecene differentially affect bone marrow cells of the lymphoid and myeloid lineages. Toxicol Appl Pharmacol. 2006; 213(2): 105-116.

19. Hodgson E. A Textbook of modern toxicology. third. Hodgson Ernest, editor. North Carolina; 2004.
20. Kammann U, Brinkmann M, Freese M, Pohlmann J-D, Stoffels $S$, Hollert $H$, et al. PAH metabolites, GST and $E R O D$ in European eel (Anguilla anguilla) as possible indicators for eel habitat quality in German rivers. Environ Sci Pollut Res Int. 2014; 21(4): 2519-2530.

21. Wiegand $H$, Boesch-Saadatmandi $C$, Regos I, Treutter $D$, Wolffram S, Rimbach $G$. Effects of quercetin and catechin on hepatic glutathione-S transferase (GST), $N A D(P) H$ quinone oxidoreductase 1 (NQO1), and antioxidant enzyme activity levels in rats. Nutr Cancer. 2009; 61(5): 717-722.

22. Kang ZC, Tsai S-J, Lee H. Quercetin Inhibits Benzo. Nutr Cancer. 1999; 35(2): 175-179. 